\title{
Bifunctional Synergy in CO Hydrogenation to Methanol with Supported Cu
}

Nielsen, Niels D.; Thrane, Joachim; Jensen, Anker D.; Christensen, Jakob M.

Published in:

Catalysis Letters

Link to article, DOI:

10.1007/s10562-019-03036-7

Publication date:

2020

Document Version

Peer reviewed version

Link back to DTU Orbit

Citation (APA):

Nielsen, N. D., Thrane, J., Jensen, A. D., \& Christensen, J. M. (2020). Bifunctional Synergy in CO Hydrogenation to Methanol with Supported Cu. Catalysis Letters, 150, 1427-1433. https://doi.org/10.1007/s10562-019-03036-7

\section{General rights}

Copyright and moral rights for the publications made accessible in the public portal are retained by the authors and/or other copyright owners and it is a condition of accessing publications that users recognise and abide by the legal requirements associated with these rights.

- Users may download and print one copy of any publication from the public portal for the purpose of private study or research.

- You may not further distribute the material or use it for any profit-making activity or commercial gain

- You may freely distribute the URL identifying the publication in the public portal

If you believe that this document breaches copyright please contact us providing details, and we will remove access to the work immediately and investigate your claim. 


\author{
Bifunctional synergy in $\mathrm{CO}$ hydrogenation to methanol with supported $\mathrm{Cu}$ \\ Niels D. Nielsen, Joachim Thrane, Anker D. Jensen and Jakob M. Christensen* \\ Department of Chemical and Biochemical Engineering, Technical University of Denmark, \\ Søltofts Plads B229, 2800 Kgs. Lyngby (Denmark). \\ *Correspondence to: jmc@kt.dtu.dk
}

\begin{abstract}
Future energy storage could be distributed at local plants and involve production of methanol from reaction of sustainably derived hydrogen with $\mathrm{CO}$ or $\mathrm{CO}_{2}$ from locally available carbon sources. Such decentralized production would benefit from milder operating conditions than found in the current large-scale industrial process. We propose that a route via $\mathrm{CO}$ hydrogenation deserves consideration for this purpose, as it will be free of water, which is unavoidable from $\mathrm{CO}_{2}$ containing gas and strongly inhibiting to the methanol synthesis at lower temperatures. On pure $\mathrm{Cu}$ the rate of methanol synthesis from $\mathrm{CO}$ is an order of magnitude lower than the rate from $\mathrm{CO}_{2}$, but active $\mathrm{CO}$ hydrogenation catalysts can emerge from a bifunctional mechanism in catalysts that combine copper with a basic oxide. Mechanistic studies are consistent with the bifunctional $\mathrm{Cu} /$ support synergy arising from a mechanism, where basic oxide sites activate $\mathrm{CO}$ as formates at the metal/oxide interface followed by metal assisted hydrogenation of the interfacial formates. Active catalysts for $\mathrm{CO}$ hydrogenation are strongly inhibited by $\mathrm{CO}_{2}$, which forms carbonates that block the basic oxide sites and thereby prevent the synergistic pathway from $\mathrm{CO}$.

Keywords: Methanol, $\mathrm{CO}$ and $\mathrm{CO}_{2}$ hydrogenation, Support effects, Copper catalyst, Bifunctional
\end{abstract}

mechanism

\title{
1. Introduction
}

Methanol synthesis from syngas $\left(\mathrm{CO} / \mathrm{CO}_{2} / \mathrm{H}_{2}\right)$ at $500-600 \mathrm{~K}$ and $5-10 \mathrm{MPa}$ over $\mathrm{Cu} / \mathrm{ZnO} / \mathrm{Al}_{2} \mathrm{O}_{3}$ catalysts is a major industrial process [1]. However, future uses of the reaction to store renewable energy in the form of methanol [2] could involve a decentralized production of methanol, where milder reaction conditions would be especially beneficial. While there is a major research focus on $\mathrm{CO}_{2}$ hydrogenation [1, 3-5], the synthesis of methanol from $\mathrm{CO} / \mathrm{H}_{2}$ should not be neglected in the search for improved low-temperature systems. An advantage of the route from $\mathrm{CO} / \mathrm{H}_{2}$ is that the atmosphere will be free of water, which is unavoidable from $\mathrm{CO}_{2}$-containing gas and strongly inhibiting to the methanol synthesis - especially at lower temperatures [6-9]. At lower temperatures $(<473 \mathrm{~K})$ a few $\mathrm{kPa}$ of water partial pressure is sufficient to eliminate the majority of the activity for $\mathrm{Cu}$-based methanol synthesis catalysts [6, 7]. As $\mathrm{H}_{2} \mathrm{O}$ adsorption isotherms on $\mathrm{Cu}[10]$ or $\mathrm{Cu} / \mathrm{ZnO} / \mathrm{Al}_{2} \mathrm{O}_{3}$ [10-12] also suggest that a high coverage is reached at $\mathrm{H}_{2} \mathrm{O}$ pressures of a few $\mathrm{kPa}$ the inhibition can largely be attributed to competitive adsorption (illustrated in supplementary information, figs. S1 \& S2). This is likely to be one of the factors that confine the industrial process to higher $\left(>500 \mathrm{~K}\right.$ ) temperatures. Consequently, from $\mathrm{CO}_{2}$ it could be difficult to reach a high yield with a high reaction rate at lower temperatures due to inhibition from the coproduced water.

Future energy storage could involve synthesis of methanol from sustainably derived hydrogen and $\mathrm{CO}_{2}$ from locally available point sources. The inhibition by water means that it is difficult to achieve a high methanol yield directly from a $\mathrm{CO}_{2} / \mathrm{H}_{2}$ feed, but there are process concepts $[13,14]$ where the $\mathrm{CO}_{2} / \mathrm{H}_{2}$ feed is first partially shifted to $\mathrm{CO} / \mathrm{CO}_{2} / \mathrm{H}_{2}$ (and formed water is removed) and then converted to methanol. This allows methanol synthesis with the conventional catalyst, as the 
$\mathrm{CO}$ in the syngas can help to remove water formed during methanol synthesis by the shift reaction. However, these concepts are still limited to the harsher synthesis conditions (500-600 K, 5-10 $\mathrm{MPa})$ of the current industrial process. When seeking a process for synthesis of methanol at milder conditions it is worth considering a process, where the $\mathrm{CO}_{2}$ is fully converted to $\mathrm{CO}$ (e.g. by watergas shift or electrolysis) followed by methanol synthesis from $\mathrm{CO} / \mathrm{H}_{2}$. The pathway from $\mathrm{CO} / \mathrm{H}_{2}$ will both have a more favorable equilibrium [15] and as water is not formed from $\mathrm{CO} / \mathrm{H}_{2}$ the reaction will be free of water inhibition. Both of these factors could lead to improved lowtemperature performance, and some $\mathrm{Cu}$-based catalysts are able to achieve considerable methanol synthesis rates from $\mathrm{CO} / \mathrm{H}_{2}$ at lower temperatures $[16,17]$

These considerations imply that it is of potential importance to elucidate the active sites and mechanism for $\mathrm{CO}$ hydrogenation on $\mathrm{Cu}$-based catalysts. Additionally, the $\mathrm{CO}$ hydrogenation can offer fundamental insights into support effects, as single crystal studies $[15,18]$ suggest that $\mathrm{Cu}$ itself has little or no activity for $\mathrm{CO}$ hydrogenation, whereas supported $\mathrm{Cu}$ catalysts can exhibit catalytic activity with a strong support effect [19]. Here we seek to elucidate the reaction mechanism and the support effect.

\section{Methods}

Here $\mathrm{Cu} / \mathrm{MgO}(20 \mathrm{wt} \%), \mathrm{Cu} / \mathrm{ZnO} / \mathrm{Al}_{2} \mathrm{O}_{3}(56 \mathrm{wt} \%), \mathrm{Cu} / \mathrm{Al}_{2} \mathrm{O}_{3}(50 \mathrm{wt} \%)$, unsupported $\mathrm{Cu}$ and $\mathrm{Cu} / \mathrm{C}$ $(15 \mathrm{wt} \%)$ were all prepared by precipitation methods (nominal $\mathrm{Cu}$ loading in parentheses). $\mathrm{Cu}-$ MOR was prepared by ion-exchanging $\mathrm{Cu}$ into mordenite, and $\mathrm{Cu} / \mathrm{SiO}_{2}(20 \mathrm{wt} \%)$ and $\mathrm{MgO} / \mathrm{C}$ were prepared by incipient wetness impregnation. Raney $\mathrm{Cu}$ was acquired from Strem Chemicals. Catalytic tests were conducted using two different high-pressure setups. One of these is described elsewhere[20] and the other is described in detail in the supporting information. CO chemisorption, temperature programmed reactions (TPR) on model systems and $\mathrm{Cu}$ surface area measurements by $\mathrm{N}_{2} \mathrm{O}$ uptake with the reactive frontal chromatography method [21] were performed with a Quantachrome Autosorb $\mathrm{iQ}_{2}$ setup. Combined TPR and diffuse reflectance infrared Fourier transform spectroscopy (DRIFTS) was conducted in a Harrick Scientific domed reaction chamber and Praying Mantis DRIFTS unit. This was done with a Nicolet iS50 FTIR Spectrometer with a liquid- $\mathrm{N}_{2}$ cooled MCT detector. X-ray photoelectron spectroscopy (XPS) analyses were performed with a monochromatic and micro-focused Al K-Alpha source equipped with a $180^{\circ}$ double focusing hemispherical analyzer with a Thermo Scientific 128-channel detector. Further experimental details are provided in the supporting information.

\section{Results and discussion}

Fig. 1 illustrates that in high pressure methanol synthesis the $\mathrm{CO}$ hydrogenation is around an order of magnitude slower than $\mathrm{CO}_{2}$ hydrogenation for unsupported $\mathrm{Cu}$, Raney $\mathrm{Cu}$ and $\mathrm{Cu}-\mathrm{rich}$ $\mathrm{Cu} / \mathrm{Al}_{2} \mathrm{O}_{3}$. These samples are all expected to approximate the intrinsic properties of $\mathrm{Cu}$. This is in good agreement with the negligible $\mathrm{CO}$ hydrogenation observed in $\mathrm{Cu}$ single crystal studies performed at low pressure $[15,18]$. Ex situ XPS analyses on the fresh and spent unsupported $\mathrm{Cu}$ showed that the surface only contained $\mathrm{Cu}$ (and $\mathrm{O}$ due to the ex situ analysis) and showed that no $\mathrm{Ni}$ or Fe deposition from carbonyls occurred (see supplementary information). For Cu-catalyzed methanol synthesis by $\mathrm{CO}_{2}$ hydrogenation there is a strong support effect $[22,23]$, but there is generally also a linear correlation between activity and metallic $\mathrm{Cu}$ surface area [24-26], which indicates that the reaction occurs on the metallic surface. However, this (fig. S8) and other studies $[24,27]$ observe no such correlation for $\mathrm{CO}$ hydrogenation in good agreement with the limited ability of the metallic $\mathrm{Cu}$ surface to form methanol from $\mathrm{CO}$ (fig. 1). Some theoretically 
hypothesized mechanisms [28-30] suggest a faster pathway from $\mathrm{CO}$ compared to $\mathrm{CO}_{2}$ on $\mathrm{Cu}$, but both high pressure (fig. 1) and low pressure [15, 18] studies contradict this view, and this emphasizes the continued need for theoretical studies of methanol synthesis reactions.

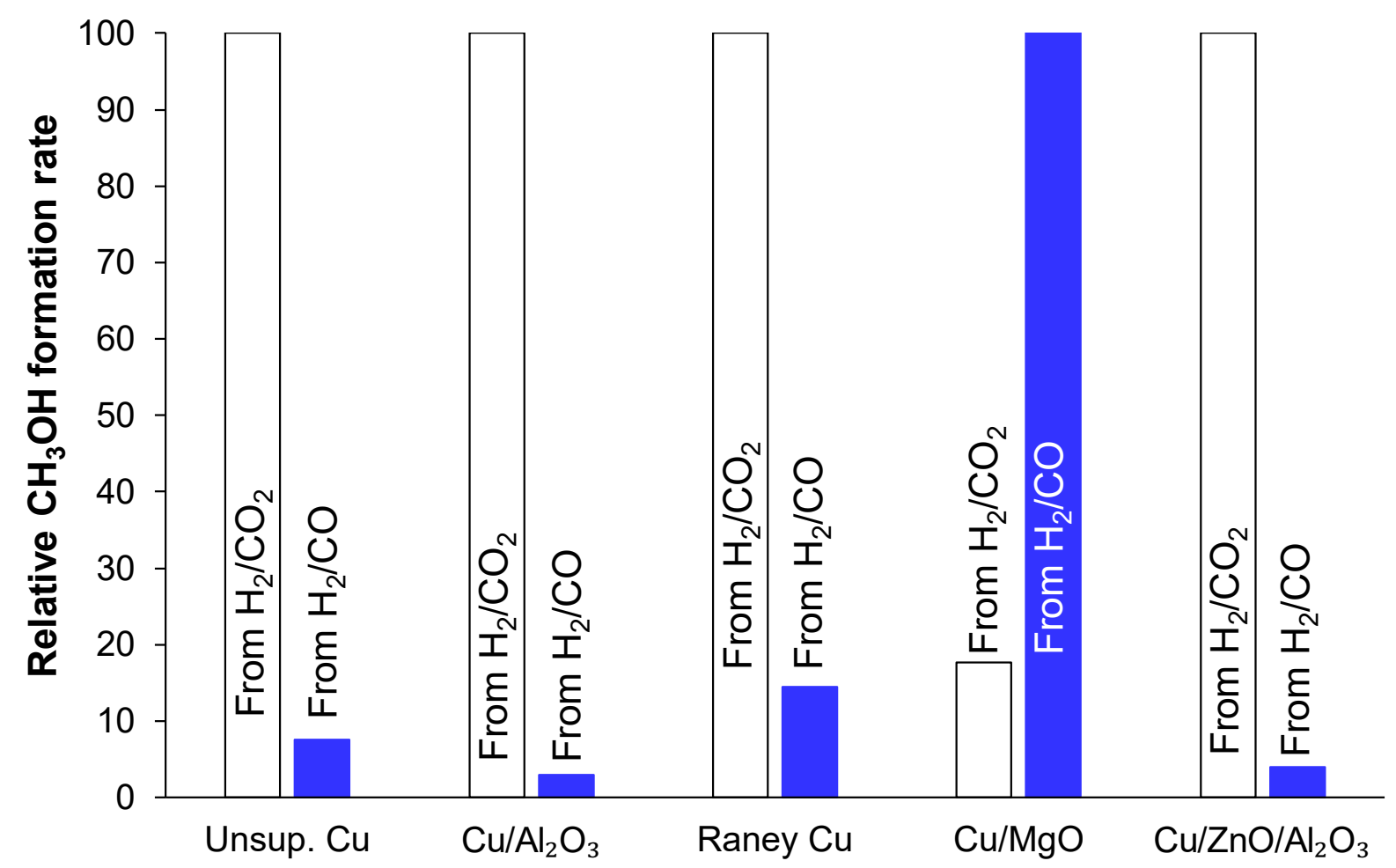

Fig. 1. The relative methanol production rates from $\mathrm{CO} / \mathrm{H}_{2}$ (blue) and $\mathrm{CO}_{2} / \mathrm{H}_{2}$ (white) over unsupported $\mathrm{Cu}, \mathrm{Cu}$-rich $(50 \mathrm{wt} \% \mathrm{Cu}) \mathrm{Cu} / \mathrm{Al}_{2} \mathrm{O}_{3}$, Raney $\mathrm{Cu}$ and $20 \mathrm{wt} \% \mathrm{Cu}$ on $\mathrm{MgO}$. The methanol production in the most reactive atmosphere is assigned as 100 for each sample. Reaction conditions: $5 \mathrm{MPa}, \mathrm{H}_{2} / \mathrm{CO}_{\mathrm{x}} /$ inert $=68 / 3 / 29$, and $523 \mathrm{~K}$ ( $498 \mathrm{~K}$ for unsupported $\mathrm{Cu}$ due to poor thermal stability). Details on absolute productivity levels are provided in supporting information figs. S3-S7.

Fig. 1 also illustrates the role of the support in achieving CO hydrogenation activity. When compared to the three samples expected to represent the intrinsic properties of $\mathrm{Cu}$ the relative rates of the industry-type catalyst $\mathrm{Cu} / \mathrm{ZnO} / \mathrm{Al}_{2} \mathrm{O}_{3}$ correspond to the intrinsic behavior of $\mathrm{Cu}$. However, the relative rates of the $\mathrm{CO}$ and $\mathrm{CO}_{2}$ pathways are completely inverted for $\mathrm{Cu}$ on an $\mathrm{MgO}$ support. Fig. 2 shows that this $\mathrm{CO}$ hydrogenation activity in $\mathrm{Cu} / \mathrm{MgO}$ emerges from a $\mathrm{Cu} /$ oxide synergy. Co-precipitated $\mathrm{Cu} / \mathrm{MgO}$ is of high activity for $\mathrm{CO}$ hydrogenation, and whereas $\mathrm{Cu} / \mathrm{C}$ and $\mathrm{MgO} / \mathrm{C}$ are of negligible activity, $\mathrm{MgO} / \mathrm{Cu} / \mathrm{C}$ prepared by impregnating $\mathrm{Mg}(\mathrm{HCOO})_{2}$ onto the essentially inactive $\mathrm{Cu} / \mathrm{C}$ catalyst shows a clear improvement in activity. This illustrates that the activity emerging in the $\mathrm{Cu} / \mathrm{MgO}$ combination is the result of a synergy between two components ( $\mathrm{Cu}$ and $\mathrm{MgO}$ ) of low individual activity. 


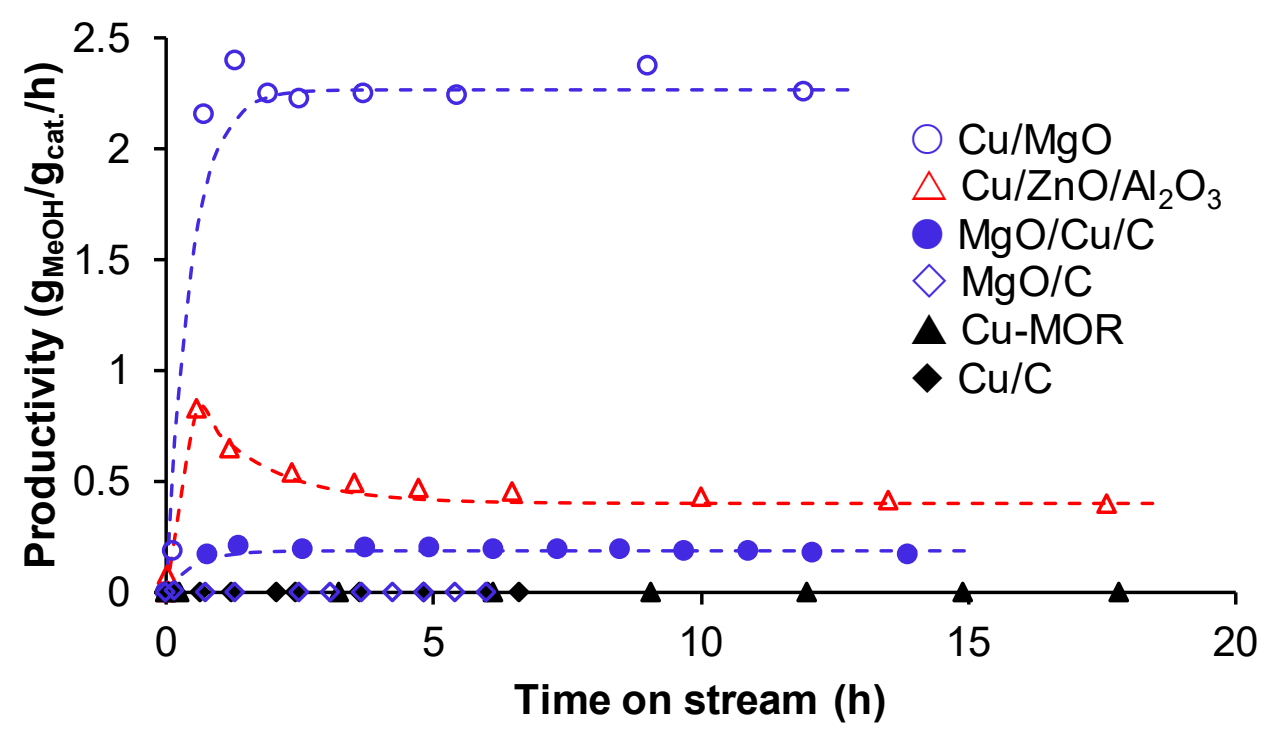

Fig. 2. Methanol synthesis rate in $\mathrm{CO}$ hydrogenation as a function of time on stream for various supported $\mathrm{Cu}$ catalysts. Reaction conditions: $\mathrm{T}=523 \mathrm{~K}, \mathrm{P}=5 \mathrm{MPa}$, flow $=300 \mathrm{NmL} / \mathrm{min}, 0.5 \mathrm{~g}$ cat., $\mathrm{H}_{2} / \mathrm{CO}=67 / 33$.

Previous studies [31-33] have established a correlation between $\mathrm{Cu}^{+}$-type surface sites and methanol synthesis activity from $\mathrm{CO} / \mathrm{H}_{2}$. On metallic $\mathrm{Cu} \mathrm{CO}$ desorbs at sub-ambient temperatures, and stable chemisorption at ambient temperature is only achieved on $\mathrm{Cu}^{+}$-type sites, where $\mathrm{CO}$ is more strongly bound $[34,35]$. CO chemisorption at $303 \mathrm{~K}$ and subsequent TPD shows that with the exception of $\mathrm{Cu} / \mathrm{C}$ all the catalysts investigated in fig. 2 have $\mathrm{Cu}^{+}$-type sites ascribed to bridging " $\mathrm{Cu}^{\delta^{+}}$-O-support" sites at the metal/oxide interface (table S1 and fig. S9). The CO chemisorption capacities of $\mathrm{Cu} / \mathrm{MgO}\left(143 \mu \mathrm{mole} / \mathrm{g}_{\text {cat. }}\right)$ and $\mathrm{MgO} / \mathrm{Cu} / \mathrm{C}\left(25 \mu \mathrm{mole} / \mathrm{g}_{\text {cat. }}\right)$ suggest that a major reason for the difference in activity between the two $\mathrm{Cu}-\mathrm{MgO}$ systems (fig. 2) is the number of these interfacial $\mathrm{Cu}^{\delta^{+}}-\mathrm{O}-\mathrm{Mg}$ sites, which indicates that a key to making active $\mathrm{CO}$ hydrogenation catalysts is to maximize the number of interfacial sites. However, a material such as $\mathrm{Cu} / \mathrm{SiO}_{2}$ has a relatively high $\mathrm{Cu}^{\delta^{+}} / \mathrm{Cu}^{0}$ ratio in the surface (table S1), but only a modest activity (fig. S7), and an ion-exchanged $\mathrm{Cu}$-mordenite sample (Cu-MOR) prepared specifically as a $\mathrm{Cu}^{+}$model system is completely without activity (fig. 2) despite a large number of the $\mathrm{CO}$ adsorption sites attributable to $\mathrm{Cu}^{+}$species (table $\mathrm{S} 1$ and fig. S9). Consequently, $\mathrm{Cu}^{+}$sites are most likely not an exclusive requirement for activity. It is therefore not only the extent of the metal/oxide interface that is important, but also the nature of the interfacial sites. The importance of the sites at the metal/oxide interface most likely arises, as it is here that the two elements of a bi-functional mechanism come together.

The argument for the existence of a bifunctional mechanism comes from the results in fig. 3 . Fig. 3a shows that $\mathrm{Cu} / \mathrm{MgO}$ exposed to $\mathrm{CO} / \mathrm{H}_{2}$ at $523 \mathrm{~K}$ exhibits infrared bands characteristic of formate $\left(1340,1625,2847\right.$ and $\left.2925 \mathrm{~cm}^{-1}\right)$ [36] and methoxide $\left(1086,2600\right.$ and $\left.2810 \mathrm{~cm}^{-1}\right)$ [37] on the $\mathrm{MgO}$. The formation of formate $(\mathrm{HCOO})$ by reaction of $\mathrm{CO}$ with basic $\mathrm{OH}$ species is a well established reaction on oxide surfaces [38,39], and the oxide can thereby activate $\mathrm{CO}$ as formate. We propose that the facile $\mathrm{CO}$ hydrogenation on materials such as $\mathrm{Cu} / \mathrm{MgO}$ proceeds via formate (HCOO) created from insertion of $\mathrm{CO}$ into a basic $\mathrm{OH}$ group from the oxide as illustrated in fig. 4. This mechanism will take place at the interface between metal and oxide. 
There are several arguments for a mechanism via formate. Fig. $3 \mathrm{~b}$ shows that temperature programmed hydrogenation (TPH) of the surface species on $\mathrm{Cu} / \mathrm{MgO}$ after exposure to $\mathrm{CO} / \mathrm{H}_{2}$ leads to methanol production in two peaks centered at $423 \mathrm{~K}$ and $523 \mathrm{~K}$. Fig. 3c shows that a model system, where magnesium formate was impregnated onto pre-reduced (and passivated) $\mathrm{Cu} / \mathrm{SiO}_{2}$ and then subjected to TPH, produced methanol at the same two temperatures. This would be consistent with the methanol-forming intermediates from $\mathrm{CO} / \mathrm{H}_{2}$ being formate species. Figs. $3 \mathrm{~b}$ and $3 \mathrm{~d}$ show that the $423 \mathrm{~K}$ methanol formation peak coincides with the disappearance of a species with IR bands $\left(1360 \mathrm{~cm}^{-1}\right.$ and $\left.2834 \mathrm{~cm}^{-1}\right)$ typical [40, 41] of $\mathrm{H}-\mathrm{C}$ and symmetric O-C-O stretches in bidentate formate. This suggests that such a formate is the origin of the most facile methanol formation at $423 \mathrm{~K}$. Efficient $\mathrm{CO}$ hydrogenation catalysts such as $\mathrm{Cu} / \mathrm{MgO}$ (fig. 2) and $\mathrm{Cu} / \mathrm{CeO}_{2}$ $[16,17]$ include oxides that efficiently produce formate from $\mathrm{CO}+\mathrm{OH}$ reactions (see fig. 3a for $\mathrm{MgO}$ and $\mathrm{Li}$ et al.[42] for $\mathrm{CeO}_{2}$ ). A reliance on basic $\mathrm{OH}$ groups explains why the supports/promoters providing higher $\mathrm{CO}$ hydrogenation activity, such as $\mathrm{MgO}$ and $\mathrm{ZnO}$ (fig. 2), alkali oxides [43] and rare earth oxides [16, 17] all are of a basic character [44, 45]. Additionally, previous $\mathrm{C}^{16} \mathrm{O} / \mathrm{C}^{18} \mathrm{O}$ isotope labeling studies [46] with $\mathrm{Na}_{2} \mathrm{O}-\mathrm{Pd} / \mathrm{SiO}_{2}$ have shown than in such systems combining a metal with a basic oxide the $\mathrm{C}-\mathrm{O}$ bond in methanol is scrambled compared to the $\mathrm{CO}$ reactant. This is consistent with a mechanism via the two-oxygen formate intermediate, where either oxygen can end in the product molecule.
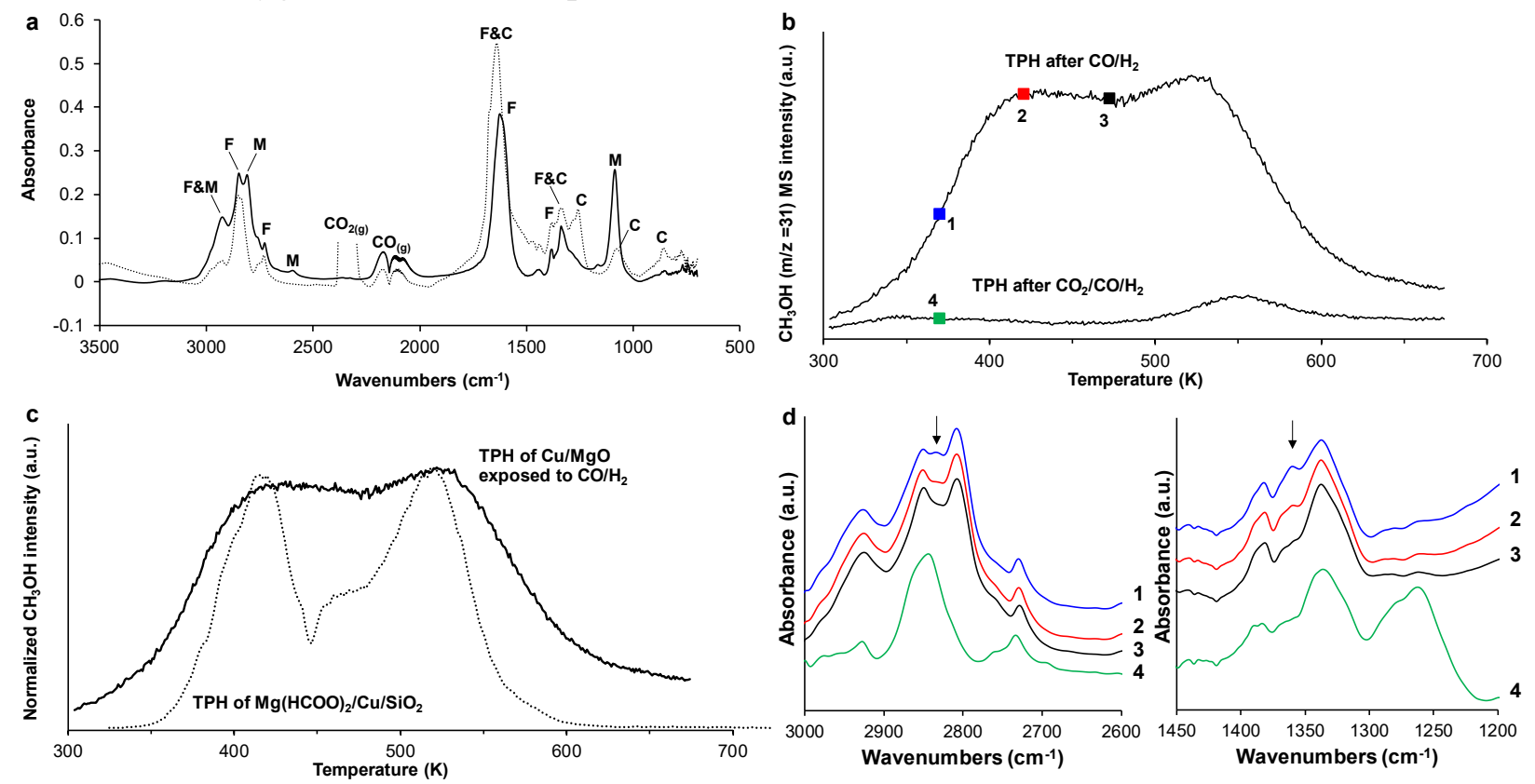

Fig. 3 a) FTIR spectra of $\mathrm{Cu} / \mathrm{MgO}$ at $523 \mathrm{~K}$ and atmospheric pressure in flowing $\mathrm{CO} / \mathrm{H}_{2}$ (full line) or $\mathrm{CO}_{2} / \mathrm{CO} / \mathrm{H}_{2}$ (dotted line) with indications of formate $(\mathrm{F})$, methoxide $(\mathrm{M})$ and carbonate/bicarbonate (C). Conditions: $\mathrm{CO} / \mathrm{H}_{2} /$ inert $=3 / 68 / 29, \mathrm{CO}_{2} / \mathrm{CO} / \mathrm{H}_{2} /$ inert $=1.5 / 1.5 / 68 / 29$. b) Methanol $(\mathrm{m} / \mathrm{z}=31) \mathrm{MS}$ intensity as a function of temperature during $\mathrm{TPH}$ of the $\mathrm{Cu} / \mathrm{MgO}$ catalyst after the exposure to $\mathrm{CO} / \mathrm{H}_{2}$ or $\mathrm{CO}_{2} / \mathrm{CO} / \mathrm{H}_{2}$ at $523 \mathrm{~K}$ and atm. pressure (and cooling in this gas). Numbers indicate the positions of the spectra in fig. $3 \mathrm{~d} .2 \mathrm{~K} / \mathrm{min}, 50 \mathrm{NmL} / \mathrm{min} \mathrm{H}_{2}$ flow, $10 \mathrm{mg}$ catalyst. c) Normalized methanol $(\mathrm{m} / \mathrm{z}=31) \mathrm{MS}$ intensity as a function of temperature comparing $\mathrm{CO} / \mathrm{H}_{2}$ treated $\mathrm{Cu} / \mathrm{MgO}$ to $\mathrm{Mg}(\mathrm{HCOO})_{2} \cdot 2 \mathrm{H}_{2} \mathrm{O}$ impregnated to $5 \mathrm{wt} \% \mathrm{Mg}$ on prereduced and passivated $20 \mathrm{wt} \% \mathrm{Cu} / \mathrm{SiO}_{2}$. Ramp in both cases: $2 \mathrm{~K} / \mathrm{min}, 50 \mathrm{NmL} / \mathrm{min} \mathrm{H}_{2}$ and 10 mg catalyst for $\mathrm{Cu} / \mathrm{MgO}, 30 \mathrm{NmL} / \mathrm{min}_{2}$ and $0.5 \mathrm{~g}$ catalyst for $\mathrm{Mg}(\mathrm{HCOO})_{2} / \mathrm{Cu} / \mathrm{SiO}_{2}$. d) FTIR 
spectra at points 1-4 along the TPH experiments in fig. 3b. The arrows mark $1360 \mathrm{~cm}^{-1}$ and 2834 $\mathrm{cm}^{-1}$.

An alternative pathway via the mono-oxygenated intermediates formyl ( $\mathrm{HCO}$ ), formaldehyde $\left(\mathrm{H}_{2} \mathrm{CO}\right)$ and methoxide $\left(\mathrm{CH}_{3} \mathrm{O}\right)$ is the basis of several [4, 28-30] proposed mechanisms for $\mathrm{CO}$ hydrogenation. For unsupported $\mathrm{Cu}$ such a mechanism seems like the only option, since there is no oxide support to facilitate the creation of a two-oxygen species. That unsupported $\mathrm{Cu}$ does have a low, but non-zero formation of methanol from $\mathrm{CO}$ (fig. 1) suggests that such a direct mechanism exists. However, for an efficient $\mathrm{CO}$ hydrogenation catalyst like $\mathrm{Cu} / \mathrm{MgO}$ it is formate-type IR bands (assigned to interfacial species) that correlate to methanol formation in fig. $3 \mathrm{~d}$ whereas a characteristic IR band of formyl (2660-2680 $\left.\mathrm{cm}^{-1}\right)$ [47] was absent in the methanol forming situations in fig. $3 \mathrm{~d}$. While the present results therefore offer support to the intermediate role of interfacial formate species there is nothing in the present results to suggest an important role of formyl for an active catalyst such as $\mathrm{Cu} / \mathrm{MgO}$.

$\mathrm{The} \mathrm{Cu} / \mathrm{MgO}$ catalyst exposed to $\mathrm{CO} / \mathrm{H}_{2}$ produces methanol in two peaks during TPH (fig. $3 \mathrm{~b})$. Fig. 3d suggests that the $423 \mathrm{~K}$ methanol formation coincides with a species having IR bands characteristic of formate $\left(1360 \mathrm{~cm}^{-1}\right.$ and $\left.2834 \mathrm{~cm}^{-1}\right)$. These bands are different from those of formate entirely on $\mathrm{MgO}$ [36], but Fig. 3d shows that this species is formed from CO implying a role of surface $\mathrm{OH}$ from the oxide. Fig. $3 \mathrm{~d}$ also shows that this species is not formed from $\mathrm{CO}_{2} / \mathrm{CO} / \mathrm{H}_{2}$. This counts against it being formate entirely on the metallic surface, where it is well established that formate is produced from $\mathrm{CO}_{2}$ and $\mathrm{H}_{2}$ [48]. Consequently, the species forming methanol at $423 \mathrm{~K}$, which does not appear to be entirely on either metal or oxide, is attributed to formate at the metal/oxide interface, possibly a bridging formate across the interface. This species is assigned as the primary reaction intermediate, as it can form methanol at a relatively lower temperature. A pathway to methanol via interfacial formates is supported by studies [4951] of $\mathrm{Cu}$ on $\mathrm{ZrO}_{2}$. The higher temperature $(523 \mathrm{~K})$ methanol formation coincides with the general disappearance of formates and methoxides entirely on the $\mathrm{MgO}$ (figs. S10 and S11) and is thus assigned to the less facile conversion of such species entirely on the oxide.

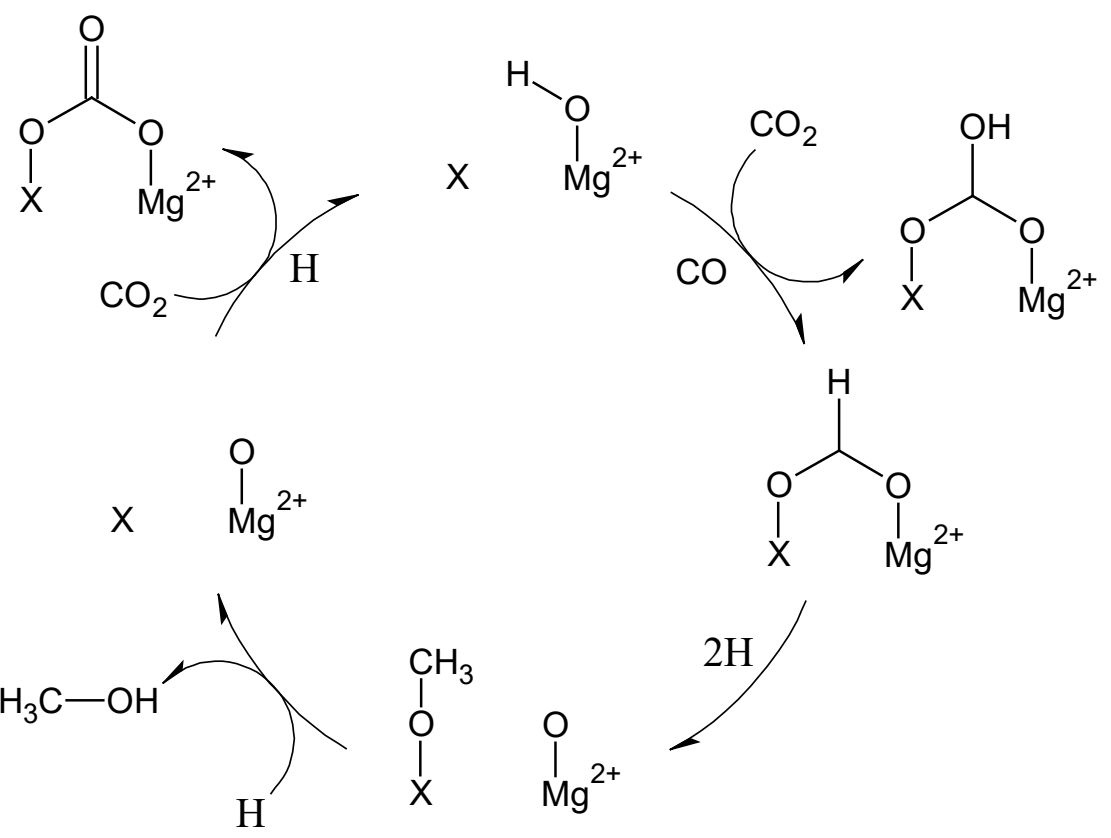


Fig. 4. The proposed oxide assisted mechanism for methanol synthesis via formate and methoxide. Here $\mathrm{X}$ can represent both $\mathrm{Cu}$ or $\mathrm{Mg}$ with $\mathrm{X}=\mathrm{Cu}$ implying a bridging formate across the $\mathrm{Cu}$ /oxide interface. The scheme also illustrates the deactivating effect of $\mathrm{CO}_{2}$. Although illustrated for $\mathrm{MgO}$ other oxides with basic sites should perform similarly.

Contrary to the behavior of $\mathrm{Cu}$ itself (fig. 1) both this (fig. S12) and other studies [19, 29, 52] observe that catalysts with a high activity from $\mathrm{CO} / \mathrm{H}_{2}$, such as $\mathrm{Cu} / \mathrm{MgO}$, are strongly inhibited by $\mathrm{CO}_{2}$. The inhibition is largely reversible upon removal of $\mathrm{CO}_{2}$ (fig. S6). Fig. 3a shows that when $\mathrm{Cu} / \mathrm{MgO}$ is exposed to $\mathrm{CO}_{2} / \mathrm{CO} / \mathrm{H}_{2}$ IR bands characteristic of carbonates and bicarbonates appear. An experiment, where $\mathrm{Cu} / \mathrm{MgO}$ was exposed to $\mathrm{CO}_{2}$ alone to produce carbonates (fig. S13), clearly illustrates that carbonates contribute to the bands at 858,1078, 1340 and $1630 \mathrm{~cm}^{-1}$ in good agreement with the literature $[53,54]$. The band at $1254 \mathrm{~cm}^{-1}$ occurring in $\mathrm{CO}_{2} / \mathrm{CO} / \mathrm{H}_{2}$ is most likely carbonate in a particular configuration bridging two metal atoms/ions [54], but this species is only formed by $\mathrm{CO}_{2} / \mathrm{CO} / \mathrm{H}_{2}$ and not by $\mathrm{CO}_{2}$ alone (fig. S13) - possibly because it is a bicarbonate species. The $\mathrm{Cu} / \mathrm{MgO}$ catalyst exposed to $\mathrm{CO}_{2} / \mathrm{CO} / \mathrm{H}_{2}$ produces considerably less methanol in the subsequent TPH, which suggests that inhibition is due to a blocking effect of the carbonates that displaces the methanol forming intermediates. Most importantly, the absence of the $423 \mathrm{~K}$ methanol formation (fig. 3b) and the 1360 and $2834 \mathrm{~cm}^{-1}$ IR bands (fig. 3d) shows that the more reactive species assigned as interfacial formates are completely displaced in conjunction with the carbonate formation. This can explain the inhibiting effect of $\mathrm{CO}_{2}$. In the presence of $\mathrm{CO}_{2}$ the basic oxide sites that are necessary for the bifunctional synergy are blocked as inactive carbonates (as indicated in fig. 4), and the formation of the mechanistically important interfacial formates relying on basic $\mathrm{OH}$ groups is prevented. The inhibiting effect of $\mathrm{CO}_{2}$ on a bifunctional pathway from $\mathrm{CO}$ might not be limited to the highly basic oxide supports such as $\mathrm{MgO}$. It is possible that such a COpathway is also inhibited on less basic oxides, when $\mathrm{CO}_{2}$ is present. It only appears to be the bifunctional pathway from $\mathrm{CO}$ that is inhibited by $\mathrm{CO}_{2}$. In the presence of $\mathrm{CO}_{2}$ the methanol formation rate suggests that $\mathrm{Cu}$ metal surface produces methanol from the $\mathrm{CO}_{2}$ with its expected rate (table $\mathrm{S} 2$ ).

Whereas the interfacial formate species are assigned as the key intermediates in the $\mathrm{CO}$ hydrogenation the formate and methoxide species entirely on the $\mathrm{MgO}$ are only expected to play a limited role in the methanol synthesis, perhaps that of complete spectators. Firstly, these species are only converted at higher temperatures during TPH (figs. S10 and S11). Secondly, the IR bands of formate on $\mathrm{MgO}$ are not strongly affected by the presence of $\mathrm{CO}_{2}$ (fig. 3a), which affects productivity significantly. The interfacial formates are more reactive, but also less stable and more easily displaced by carbonates (fig. 3d), whereas the majority of formates entirely on the $\mathrm{MgO}$ are more stable and less reactive and therefore not displaced by carbonates (fig. 3a.). Consequently, the methanol formation is assigned to formate species specifically at the metal/oxide interface that are displaced by carbonates in the presence of $\mathrm{CO}_{2}$. It is thus likely that formate is both a spectator on the oxide surface further away from the metal particles and an actual intermediate on interfacial sites. The IR bands of methoxide on $\mathrm{MgO}$ drop significantly in the presence of $\mathrm{CO}_{2}$ (fig. 3a.). This is most likely because water is produced from the $\mathrm{CO}_{2}$-containing gas. The removal of methoxide on an oxide by hydrolysis with water is far more facile than hydrogenation [55]. The methoxide on $\mathrm{MgO}$ is most likely formed, when produced methanol is re-adsorbed on the oxide, and the combination of the slower methanol production in the presence of $\mathrm{CO}_{2}$ and the faster removal of methoxide by hydrolysis can explain the lower methoxide coverage in the $\mathrm{CO}_{2}$-containing gas. While it cannot be fully excluded that methoxide on the $\mathrm{MgO}$ can play a mechanistically important 
role under some conditions its disappearance in the presence of $\mathrm{CO}_{2}$ may just result from the presence of water that hydrolyzes the methoxide species.

The present results clearly show that the $\mathrm{CO}$ hydrogenation to methanol relies on a metal/oxide synergy and suggest that one pathway to methanol is the activation of $\mathrm{CO}$ as formate by the oxide followed by a metal-assisted hydrogenation of formate into methanol. The presence of $\mathrm{CO}_{2}$ interrupts the bifunctional synergy, as the necessary basic oxide sites are blocked as carbonates. Although developed here with $\mathrm{Cu} / \mathrm{MgO}$ the present mechanistic conclusions are expected to be valid also for other catalyst systems. As an example another system with high activity from $\mathrm{CO} / \mathrm{H}_{2}$ is $\mathrm{Cu} / \mathrm{CeO}_{2}[16,17]$, where the oxide is also able to activate $\mathrm{CO}$ as formate [42], and where the presence of $\mathrm{CO}_{2}$ also inhibits the methanol synthesis and leads to carbonate formation [52, 56]. Similarly, Pd-based catalysts for CO hydrogenation generally exhibit the same support and promoter effect where basic oxides are beneficial $[19,46]$.

\section{Conclusion}

In conclusion, we propose that it is worth considering methanol synthesis from $\mathrm{CO} / \mathrm{H}_{2}$ in the search for methanol synthesis at milder conditions. The pathway from $\mathrm{CO} / \mathrm{H}_{2}$ has a more favorable equilibrium and is free of co-produced water, which is strongly inhibiting to methanol synthesis at lower temperatures. Both factors could be advantageous for low temperature operation. The present results show that active $\mathrm{CO}$ hydrogenation catalysts such as $\mathrm{Cu} / \mathrm{MgO}$ emerge from a synergy between metal and oxide, which is attributed to a bifunctional mechanism focused at the metal/support interface. The mechanistic investigations are consistent with interfacial formates, produced by reaction of $\mathrm{CO}$ with basic $\mathrm{OH}$ groups from the oxide surface, as the important reaction intermediates. Active $\mathrm{CO}$ hydrogenation catalysts are strongly inhibited by $\mathrm{CO}_{2}$ and the results suggest that this occurs because $\mathrm{CO}_{2}$ forms carbonates at the basic oxide and thereby blocks the oxide sites that enable the bifunctional pathway. The results suggest that the key to making active $\mathrm{CO}$ hydrogenation catalysts is to engineer systems that maximize the number of interfacial sites, where $\mathrm{Cu}$ and basic oxide sites come together while ensuring the absence of species such as $\mathrm{CO}_{2}$ that can block the oxide sites. The combination of optimally engineered catalysts and the water free conditions of $\mathrm{CO}$ hydrogenation could lead to improved low temperature performance in methanol synthesis and pave the way for remote and small scale methanol-based energy storage facilities.

\section{Acknowledgements}

The Villum Foundation V-SUSTAIN grant 9455 to the Villum Center for the Science of Sustainable Fuels and Chemicals is gratefully acknowledged for funding. We thank Saint Gobain for providing the $\mathrm{SiO}_{2}$ support.

\section{References}

[1] Behrens M (2015) Recycl Catal 2:78-86.

[2] G.A. Olah, A. Goeppert, G.K.S. Prakash, Beyond Oil and Gas: The Methanol Economy

(Germany, Wiley-VCH, 2006).

[3] Studt F, Sharafutdinov I, Abild-Pedersen F, Elkjær CF, Hummelshøj JS, Dahl S, Chorkendorff I, Nørskov JK (2014) Nature Chem 6:320-324.

[4] Graciani J, Mudiyanselage K, Xu F, Baber AE, Evans J, Senanayake SD, Stacchiola DJ, Liu P, Hrbek J, Fernandez Sanz J, Rodriguez JA (2014) Science 345:546-550. 
[5] Martin O, Martín AJ, Mondelli C, Mitchell S, Segawa TF, Hauert R, Drouilly C, CurullaFerré D, Pérez-Ramírez J (2016) Angew Chem Int Ed 55:6261-6265.

[6] Bardet R, Thivolle-Cazat J, Trambouze Y (1984) Compt Rend Acad Sci Paris 299:423-425. [7] Cherifi O, Monteverdi S, Bettahar MM, Forissier M, Perrichon V (1985) Bull Soc Chim Fr:405-409.

[8] Sahibzada M, Metcalfe IS, Chadwick D (1998) J Catal 174:111-118.

[9] Saito M, Fujitani T, Takeuchi M, Watanabe T (1996) Appl Catal A 138:311-318.

[10] Sloczynski J, Grabowski R, Janas J, Skrzypek J (1991) Chem Eng Sci 46:2611-2623.

[11] Słoczyński J, Grabowski R, Janas J, Skrzypek J (1991) Chem Eng Sci 46:2599-2610.

[12] Tarasov A, Seitz F, Schlögl R, Frei E (2019) ACS Catal 9:5537-5544.

[13] Goehna H, Koenig P (1994) Chemtech 24:36-39.

[14] Joo O-S, Jung K-D, Moon I, Rozovskii AY, Lin GI, Han S-H, Uhm S-J (1999) . Ind Eng Chem Res 38:1808-1812.

[15] Maack M, Friis- Jensen H, Sckerl S, Larsen JB, Chorkendorff I (2003) Top Catal 22:151160.

[16] Owen G, Hawkes CM, Lloyd D, Jennings JR, Lambert RM, Nix RM (1987) Appl Catal 33:405-430.

[17] Shen W-, Ichihashi Y, Matsumura Y (2005) Appl Catal A 282:221-226.

[18] Nerlov J, Chorkendorff I (1998) Catal Lett 54:171-176.

[19] Fujita S, Usui M, Hanada T, Takezawa N (1995) React Kinet Catal Lett 56:15-19.

[20] Christensen JM, Mortensen PM, Trane R, Jensen PA, Jensen AD (2009) App Catal A 366:29-43.

[21] Chinchen GC, Hay CM, Vandervell HD, Waugh KC (1987) J Catal 103:79-86.

[22] Fujitani T, Saito M, Kanai Y, Kakumoto T, Watanabe T, Nakamura J, Uchijima T (1994) Catal Lett 25:271-276.

[23] Chaumette P, Courty P, Barbier J, Fortin T, Lavalley JC, Chauvin C, Kiennemann A, Idriss H, Sneeden RPA, Denise B (1988) Proc $9^{\text {th }}$ Intl Congr Catal 2:585-593.

[24] Robbins JL, Iglesia E, Kelkar CP, DeRites B (1991) Catal Lett 10:1-10.

[25] Baltes C, Vukojević S, Schüth F (2008) J Catal 258:334-344.

[26] Joyner RW, Burch R, Golunski SE, Spencer MS (1990) Catal Lett 6:151-156.

[27] Robinson W, Mol J (1988) Appl Catal 44:165-177.

[28] van Rensburg WJ, Petersen MA, Datt MS, van den Berg J-A, van Helden P (2015) . Catal Lett 145:559-568.

[29] Studt F, Behrens M, Kunkes EL, Thomas N, Zander S, Tarasov A, Schumann J, Frei E, Varley JB, Abild-Pedersen F, Nørskov JK, Schlögl R (2015) ChemCatChem 7:1105-1111.

[30] Behrens M, Studt F, Kasatkin I, Kühl S, Hävecker M, Abild-Pedersen F, Zander S, Girgsdies F, Kurr P, Kniep BL, Tovar M, Fischer RW, Nørskov JK, Schlögl R (2012) Science 336:893-897.

[31] Monnier JR, Hanrahan MJ, Apai G (1985) J Catal 92:119-126.

[32] Sheffer GR, King TS (1989) J Catal 116:488-497.

[33] Chu PJ, Gerstein BC, Sheffer GR, King TS (1989) J Catal 115:194-204.

[34] Cox DF, Schulz KH (1991) Surf Sci 249:138-148.

[35] Dandekar A, Vannice MA (1998) J Catal 178:621-639.

[36] Busca G, Lamotte J, Lavalley JC, Lorenzelli V (1987) J Am Chem Soc 109:5197-5202.

[37] Kondo J, Sakata Y, Maruya K, Tamaru K, Onishi T (1987) Appl Surf Sci 28:475-478.

[38] Shido T, Iwasawa Y (1991) J Catal 129:343-355. 
[39] Gopal PG, Schneider RL, Watters KL (1987) J Catal 105:366-372.

[40] Chutia A, Silverwood IP, Farrow MR, Scanlon DO, Wells PP, Bowker M, Parker SF, Catlow CRA (2016) Surf Sci 653:45-54.

[41] Dubois LH, Ellis TH, Zegarski BR, Kevan SD (1986) Surf Sci 172:385-397.

[42] Li C, Sakata Y, Arai T, Domen K, Maruya K, Onishi T (1989) J Chem Soc Faraday Trans 1 85:1451-1461.

[43] Herman RG (1991) Stud Surf Sci Catal 64:265-349.

[44] Martin D, Duprez D (1996) J Phys Chem 100:9429-9438.

[45] Auroux A, Gervasini A (1990) J Phys Chem 94:6371-6379.

[46] Kikuzono Y, Kagami S, Naito S, Onishi T, Tamaru K (1981) Faraday Discuss 72:135-143.

[47] Saussey J, Lavalley J-C, Lamotte J, Rais T (1982) J Chem Soc Chem Commun:278-279.

[48] Taylor PA, Rasmussen PB, Ovesen CV, Stoltze P, Chorkendorff I (1992) Surf Sci 261:191206.

[49] Fisher IA, Bell AT (1998) J Catal 178:153-173.

[50] Larmier K, Liao W-C, Tada S, Lam E, Verel R, Bansode A, Urakawa A, Comas-Vives A, Copéret C (2017). Angew Chem Int Ed 129:2358-2363.

[51] Lam E, Larmier K, Wolf P, Tada S, Safonova OV, Copéret C (2018) J Am Chem Soc 140:10530-10535.

[52] Jennings JR, Lambert RM, Nix RM, Owen G, Parker DG (1989) Appl Catal 50:157-170.

[53] Cornu D, Guesmi H, Krafft J-M, Lauron-Pernot H (2012) J Phys Chem C 116:6645-6654.

[54] Busca G, Lorenzelli V (1982) Mater Chem 7:89-126.

[55] Fujita S, Ito H, Takezawa N (1993) Bull Chem Soc Jpn 66:3094-3096.

[56] Lin L, Yao S, Liu Z, Zhang F, Na L, Vovchok D, Martinez-Arias A, Castaneda R, Lin JY,

Senanayake SD, Su D, Ma D, Rodriguez JA (2018) J Phys Chem C 122:12934-12943. 